\title{
PHLEGOPSIS ERYTHROPTERA (GOULD, 1855) AND RELATIVES (AVES, FORMICARIIDAE) AS ARMY ANT FOLLOWERS
}

EDWIN O. WILLIS

\begin{abstract}
Phlegopsis erythroptera (Formicariidae) follows army ants regularly for flushed arthropods between the Andes and the Negro/Madeira Rivers. Mainly a bird of terra firme forests, it is interspecifically aggressive. Low numbers at ant swarms are probably due to low productivity of arthropods flushed by ants on weathered terra firme soils, or to high species diversity of subordinate but active ant-following competitors in upper Amazonia. Sexual dimorphism of young and female erythroptera is attributed to low numbers over ants, so that dispersed individuals avoid attacks by bright-plumaged adult males rather than bluff them out at close range. Phlegopsis, Skutchia, Rhegmatorhina, and Gymnopithys are related to and perhaps congeneric with Pithys; all follow ants and seem a group derived from birds related to Hylophylax.

Antbirds of Phlegopsis and related genera (Formicariidae) regularly capture arthropods flushed by swarms of army ants in neotropical forests (Willis \& Oniki, 1978; Willis, 1979). Here, in the twentieth report of a series on occasionally-observed ant followers, I note new information on Phlegopsis erythroptera and related species.
\end{abstract}

\section{RESULTS}

1. Phlegopsis erythroptera (Reddish-winged Bare-Eye), a bird never seen away from ants, followed 64 ant raids in Colombia (7 Umbria, 10 Mitú, 3 Leticia), Ecuador (7 Limoncocha, 3 Zatzayacu 900 m, 10 Yaapi, 9 Putuimi), Peru (5 Andoas), and western Brazil (1 Benjamin Constant, 4 Carauari, 3 Manacapuru, 2 Igapó-Açu). One raid at Mitú was of the ant Labidus praedator; the other 63 raids were of Eciton burchelli. Five birds were at 1 raid (Limoncocha), 4 at 3 raids ( 1 Limoncocha, 2 Carauari), 3 at 10 raids (2 Leticia, 2 Zatzayacu, 1 Putuimi, 2 Andoas, 2 Carauari, 1 Manacapuru), 1 at 13 raids (1 Umbria, 3 Mitú, 1 Limoncocha, 5 Yaapi, 1 Putuimi, 1 Andoas, 1 Benjamin Constant), and 2 birds at the other raids.

Department of Biology, University of Miami, Coral Gables, Florida 33124, U.S.A., and Departamento de Zoologia, Universidade Estadual Paulista "Júlio de Mesquita Filho" - UNESP, Caixa Postal 178, 13.500 - Rio Claro, S. Paulo. 
$P$. erytnroptera show many of the characteristics of regular ant followers: they follow a line of ants to a swarm, as well as stumble on swarms directly; they visit statary or other inactive bivouacs; and they search near places where ants had been the preceding day. The species deserts ant raids that enter pastures, but follows ants into dense second growth. It occurs both in upland and in swampy forests, although I have yet to see it in seasonally flooded swamp forests where its relative $P$. nigromaculata is very common.

$P$. erythroptera normally sallies to the ground for insects from low perches over ants, much as do other dominant ant-following birds (Willis, 1979). Of 49 records of height in various regions, 46 were below $1 \mathrm{~m}$ ( 39 being from 0.2 to $0.7 \mathrm{~m}$ up) and only 3 from there to $3 \mathrm{~m}$ up. Twice one hopped on the ground. The species regularly flies up to 2 or $3 \mathrm{~m}$ above the ground when one startles it, or when moving from one part of an ant raid to another. Horizontal (6 records) and inclined perches (9) are used about as often as vertical (16) ones, for this species seems to cling close and akwardly on vertical perches as compared to many of its relatives. As in many other antbirds, most perches are slender ones (25 records were 9-9-4-1-1 by 1-cm intervals from 0-5 cm diameter, and only 1 perch was over $5 \mathrm{~cm}$ diameter). Of 66 records of prey capture, 45 were sallies to the ground and $\mathbf{1 5}$ were pecks at a trunk (2) or debris (13) for ants, while 1 each involved tossing leaves or pecking at the ground and 2 each involved pecks or short serial sallies. Sallies to the ground were never over $1.5 \mathrm{~m}$; 16 records were $9-5-2$ from $0-1.5 \mathrm{~m}$, by $0.5 \mathrm{~m}$ intervals. At times a sally involved bounding along the ground or whirling to follow prey. Prey items recorded included spiders and egg cases, a large caterpillar, and 15 ant larvae. P. erythroptera twice took over sites from small antbirds that were pecking at fleeing ants with larvae, and like the small antbirds tossed adult ants but ate the larvae as if working on an assembly line.

This is an even larger bird than its relative, Phlegopsis nigromaculata: male erythroptera at Manacapuru and Igapó-Açu weighed 51.2 and $53.2 \mathrm{~g}$, while 2 females at Manacapuru weighed 53.0 and $57.0 \mathrm{~g} P$. erythroptera aggressively dominates small birds, and usually takes the center of ant swarms by forcing other species to the edges. $P$. nigromaculata were supplanted twice and displaced twice at Limoncocha, forcing the nigromaculata to forage in vines over $1 \mathrm{~m}$ up or at the edges of swarm raids (Willis, 1979) whenever more than 2 erythroptera were present. Antbirds of the genus Rhegmatorhina are supplanted or displaced (Willis, 1969), as are Gymnopithys species: G. salvini was supplanted once at Igapó-Açu, G. leucaspis in many regions (Umbria 2 times, Limoncocha 2, Putuimi 1, Leticia 1, Manacapuru 3; leucapsis was displaced 1 time at Mitú and 3 at Yaapi). Pithys albifrons was supplanted at Umbria (1), Mitú (2) and Yaapi (3), Hylophylax poecilinota at Umbria (1), and the woodcreepers Dendrocincla fuliginosa (3) and D. merula (1) at Carauari. The large antbird Myrmeciza 
fortis was usually displaced (3) or supplanted (4), but once supplanted erythroptera at Zatzayacu. One cotinga (Phoenicircus nigricollis) flushed an erythroptera at Leticia by flying down near the ants. Like many relatives, erythroptera gives a scratchy chaik "grunting" noise every second or two when competitors are nearby.

$P$. erythroptera are also aggressive to other birds of their own species. Supplantings were 4 at Limoncocha, 6 at Leticia, and 24 at Carauari; displacings were 1 each at Zatzayacu and Putuimi. New pairs or individuals at a swarm of ants commonly cause a noisy dispute, starting with loud stit "chipping" calls and peef peef peef peef peef peef "bugling" series. The orange-red faces of disputing birds are flushed, and sleeking of the feathers of the forehead causes bare facial areas to cxpand. The tail and body feathers often are spread, and either the dominant or subordinate bird may repeatedly flash the wings downward, displaying the prominent rufous and white areas. "Puffing" chahh noises accompany supplantings, and the sleeked or cowering trespasser may be chased about the area with occasional "warbling" eep-eep-eep eu eu series (several rapid high notes followed by a few low ones). One crouching male ruffed the head feathers, thus closing the bare facial areas, and gaped. At times there is a «whining» eeyou sound, or a series of "whimpering" faint $e$ notes. Faint or loud "songs", descending series of 4-10 nasal whistles (whie, eie, ep, erp, erp, eup) at 3-5 notes/sec, may be given as disputing birds separate. One male, probably a trespasser, wiped his bill rapidly when a distant bird sang. Territorial birds sing or fly to start a dispute if another bird sings near the swarm. One male, at the bugling notes of a distant fight, flew over bushes and glided toward the combatants.

Pairs sometimes chase an intruder jointly, but often forage separately. One female stretched her neck away from the male and flew off when he alighted by her. At Zatzatyacu, 23 Oct 1965, a male repeatedly fed his mate, one or both giving warbling calls or "murmuring" chwahh series. Once he gave faint eu "chirps" with food, and the female flew to him for a feeding. The female of a pair sometimes rests ahead of ants, her feathers fluffed out over her wings, or preens as her mate works actively.

A short-billed young bird, with dark face, buff-barred back, and 3 broad rusty wing bands, was with a pair at Andoas Viejo, Peru, 2 June 1979. Several trios at ant raids included a bird in female plumage, but with rusty wing bars rather than the white wing bars of the adult female. Birds with female plumage but rusty wing bars are probably immature birds, perhaps staying with their parents. A short-tailed bird from Umbria in the Philadelphia Academy of Natural Sciences, Jan 1948, is a blackish young with buff bars on the wings and back feathers, and with a few new brown feathers of the female plumage on head and body. A young male in the American Museum of Natural History (25 Oct 1928, Mt. Duida, Venezuela) is molting from a rufous plumage like that of the young female. In the Vienna Museum, a 
similar molting young male (Rio Içana, 11 June 1831) is in wing molt, while one molting young male not in wing molt is in the Stockholm Museum (Codajás, 15 July 1935). Meyer de Schauensee (1970) says the "female" has rusty wing bars, but adult females in museums normally have white wing bars.

In alarm or excited disputes, erythroptera is like Hylophylax and related birds in repeatedly "flicking" the tail upward, from $45^{\circ}$ below the line of the body to a few degrees above the line of the body. At times a bird flits its reddish primaries outward as it flicks its tail. $P$. erythroptera "chirrs" a deep cheeowrrr, a note that is higher in pitch in the female, or chips as it flees to cover. A bird sometimes chirrs and pivots around a vertical sapling at 2 or $3 \mathrm{~m}$ up, showing of its red face as a large "eyespot" pattern, before fleeing. If one surprises an erythroptera, it may freeze briefly on its perch. It is a difficult bird to study because it hides in dense undergrowth and is very wary; but individuals, especially immatures, become tame after a few hours. Such a bird may faint-sing rather than chirr as one moves. At times, a bird jitters as ants attack its feet.

The tail is lifted above the line of the body to defecate. This bird, like most Formicariidae, scratches the head indirectly or over the wing. Fluffing out and shaking the plumage, preening, and bathing were occasionally noted.

2. Skutchia borbae (Pale-faced Antbird), subject of an earlier publication (Willis, 1968 a), was later observed and netted at 2 Eciton burchelli raids at Sucunduri, Brazil. It replaces $P$. erythroptera as the dominant ant-following antbird between the Madeira and Tapajós rivers. At Sucunduri, it supplanted Rhegmatorhina hoffmannsi once and Dendrocincla merula once (displacing the latter once). Six recent specimens of the species, 2 from near Itaituba in the Museu Goeldi at Belém and 4 from Prainha in the São Paulo Museum, show that the female lacks dusky tips on the dorsal feathers. One such female at Sucunduri preened ahead of ants as a male worked busily. Netted and photographed, this female weighed $50.1 \mathrm{~g}$ and had a body temperature of $43.4^{\circ} \mathrm{C}$. She was in wing molt (primary $n^{2} 7$ on each side was half grown) 11 Sep 1974. The tiny bare area behind the eye barely justifies the name "Bare-Eye" used by Meyer de Schauensee (1970), although the area does have a slight pink tinge due to blood vessels. The species may be related phylogenetically to red-faced Phlegopsis species rather than convergent with them, but pending a complete revision of the family Formicariidae, I still consider borbae different enough from red-faced Phlegopsis to merit generic separation.

3. Rhegmatorhina hoffmannsi (White-breasted Antbird), reported on earlier (Willis, 1969), followed 2 Eciton burchelli raids west of the river at Sucunduri, where a netted and photographed male weighed $32.9 \mathrm{~g}$ (cloacal temperature $42.2^{\circ} \mathrm{c}$ ) and a female $32.5 \mathrm{~g}$ (cloacal temperature $43.3^{\circ} \mathrm{c}$ ). The species also followed 2 burchelli raids at the Serra dos Parecis, Mato Grosso, Brazil (Willis, 1976). At the Parecis, one grown young bird accompanied two adults 15 July 1975. 
4. Rhegmatorhina gymnops (Bare-eyed Antbird), also reported on earlier (Willis, 1969), followed 3 Eciton burchelli raids at Miritituba, Brazil, across the Tapajós River from Itaituba. Protographed males weighed 30.0 and $29.9 \mathrm{~g}$, and one was in wing molt (primary no. 3 on each side nearly grown) $20 \mathrm{Sep}$ 1974. The bare face of this species is greenish-blue rather than blue, and "green" is recorded for the faces of $3 R$. berlepschi specimens in the Berlin Museum. I had not realized in my earlier publication and its illustration that gymnops and berlepschi were like hoffmannsi in this respect rather than like blue-faced $R$. melanosticta and $R$. cristata.

5. Rhegmatorhina melanosticta (Hair-crested Antbird), reported on earlier (Willis, 1969), followed 2 Eciton burchelli raids in hill forests $12 \mathrm{~km}$ E Nuevo Andoas, Peru. The species did not occur in floodplain forests along the nearby Pastaza River, where it was replaced by the following species. Failure to use floodplain forests may explain why it is rarely collected in the Amazonian lowlands, since most collectors have to work along rivers due to lack of roads. The high species diversity of ant-following birds in the upper Amazon is partly due to habitat specialization between floodplain and hill forests, for Pithys albifrons and Neomorphus geoffroyi also avoid floodplain forests near Andoas.

6. Gymnopithys lunulata (Lunulated Antbird), reported on earlier (Willis, 1968 b), followed 4 Eciton burchelli raids near the Pastaza River at Andoas Viejo, Peru. Apparently it does not occur in hill forests nearby, where $R$. melanosticta and $P$. albifrons split its niche and encroach on the niche of the relatively riverine larger Myrmeciza fortis. I was unable to find Pithys castanea in the region, and am not sure what might be its niche, but the only specimen was collected at Andoas Viejo and therefore near the river.

\section{DISCUSSION}

Antbirds of the genera Pithys, Gymnopithys, Rhegmatorhina, Phlegopsis, Skutchia, and Phaenostictus are all regular ant followers and seem to be a monophyletic assemblage. If anatomical and DNA hybridization studies eventually prove monophyly, it may be best to combine these genera under Pithys or under Gymnopithys (with Pithys as a branch genus). Without such studies, and because of the possibility of polyphyletic convergences, I am reluctant to lump genera in the Formicariidae, even though I would prefer to combine most antshrikes with Thamnophilus and many small antbirds with Drymophila as well as put most of the present genera under Pithys or Gymnopithys.

Phlegopsis erythroptera is unusual among birds of the Pithys group in being a large species with sexual dimorphism. Sexes are alike in most large species, and unlike in most small species of this group. Pithys albifrons, a small species with little sexual dimorphism, probably lacks dimorphism because this fast-moving and evasive species crowds together at the center of ant raids like a dominant or large antbird (Willis, 1981). In this case, females that look like bright males (i. e., are "male automimetic" in plumage), apparently have the advantage 
over nonautomimetic or dull-plumaged females, which would lose any bluffing contest.

$P$. erythroptera females and young males probably lack the bright plumage of adult males because this is the only species of large antbird that does not concentrate over the center of ant swarms. It is very aggressive, and one seldom sees many individuals at a swarm. Mated pairs commonly forage apart, a rare situation among large ant-following: antbirds.

I attribute lack of concentration to the fact that erythroptera normally forages in rather weathered and unproductive upland forests, where ants apparently flush little prey compared to ants in rich soils of várzea forests (where the related sexually monomorphic Phlegopsis nigromaculata congregates; Willis, 1979). Moreover, erythroptera competes with a host of species of medium and small antbirds, hence has less food available than do Central American large antbirds or large antbirds east of the Madeira River in Brazil, all of which compete with fewer species of antbirds.

Since erythroptera does not concentrate, females, and young males are less subject to intraspecific close-range disputes than to long-range disputes. In long-range disputes, it may be more important to not excite the resident male enough to cause him to fly over to attack (hence a different plumage from that of resident males is better) than to try to bluff him out at close range with a plumage as bright as his. Also, females do not have to compete at close range with males or with each other to keep a place among many birds, so that they may be more selected for dull and protective coloration for antipredator reasons.

\section{ACKNOWLEDGMENTS}

I appreciate grants from the National Science foundation and the American Museum of Natural History. Yoshika Oniki helped with the manuscript.

\section{REFERENCES}

Meyer de Schauensee, R., 1970. A guide to the birds of South America. Livingston Publishing Company, Wynnewood, Pennsylvania.

Willis, E. O., 1968a. Taxonomy and behavior of Pale-faced Antbirds. Auk 85: 253-264.

Willis, E. O., 1968b. Studies of the behavior of Lunulated and Salvin's Antbirds. Condor 70: 128-148.

Willis, E. O., 1969. On the behavior of five species of Rhegmatorhina, ant-following antbirds of the Amazon basin. Wilson Bull. 81: 363-395.

Willis, E. O., 1976. Effects of a cold wave on an Amazonian avifauna in the upper Paraguay drainage, western Mato Grosso, with comments on oscinesuboscine relationships. Acta Amazônica 6: 379-394.

Willis, E. O., 1979. Comportamento e ecologia da mãe-de-taoca, Phlegopsis nigromaculata (D'Orbigny \& Lafresnaye) (Aves, Formicariidae). Revta bras. Biol. 39: 117-159.

Willis, E. O., 1981. Diversity in adversity: the behaviors of two subordinate antbirds. Arq. Zool., S. Paulo 30: 1-77.

Willis, E. O. \& Y. Oniki, 1978. Birds and army ants. Ann. Rev. Ecol. System. 9: 243-263. 